\title{
Isolation of a Nickel-dependent Blue-green Alga
}

\author{
By C. VAN BAALEN AND RITA O'DONNELL \\ University of Texas Marine Science Institute, \\ Port Aransas Marine Laboratory, Port Aransas, Texas 78373, U.S.A.
}

(Received 24 November 1977)

\section{INTRODUCTION}

Nickel-dependent chemolithotrophic growth of Alcaligenes (Hydrogenomonas) eutrophus is well documented (Bartha \& Ordal, 1965; Repaske \& Repaske, 1976), although no discrete function for nickel has so far been identified. Nickel inhibition of fermentation in yeast was ascribed in part to inhibition of alcohol dehydrogenase (Fuhrmann \& Rothstein, 1968) while excess nickel induced an unbalanced growth condition in a marine Arthrobacter species resulting in large, plasmolysed sphaeroplasts (Cobet, Wirsen \& Jones, 1970). In Alcaligenes eutrophus, ${ }^{63} \mathrm{Ni}$ uptake in chemolithotrophically grown cells was energy dependent (Tabillion \& Kaltwasser, 1977). In the diatom Phaeodactylum tricornutum, uptake capacity depended strongly on metabolic state; phosphate-starved cells, in particular, had low nickel binding capacity which was markedly increased by addition of phosphate (Skaar, Rystad \& Jensen, 1974). The discovery that urease contained stoicheiometric amounts of nickel led to the suggestion that nickel is important in enzymes catalysing reactions involved in the utilization, production or transfer of ammonia (Dixon et al., 1976).

In the course of isolation of new strains of blue-green algae (cyanobacteria) from enrichment cultures, we observed an Oscillatoria sp. which had an absolute requirement for nickel. Its growth characteristics and certain of its physiological properties are described in this communication.

\section{METHODS}

Isolation and culture of organism. Oscillatoria sp., designated strain $3 \mathrm{NT}$, was isolated from a marine mud sample taken adjacent to the Port Aransas Marine Laboratory, on medium ASP-2 (Provasoli, McLaughlin \& Droop, 1957; Van Baalen, 1962) containing $0.042 \mu \mathrm{M}-\mathrm{NiCl}_{2} \cdot 6 \mathrm{H}_{2} \mathrm{O}$. The unialgal culture was purified by repeated streaking on agar (Difco 0140) plates of medium ASP-2. For growth rate and yield measurements, cultures were incubated in $22.5 \times 175 \mathrm{~mm}$ Pyrex tubes in a water bath, patterned after the design of Myers (1950), at 39 or $30^{\circ} \mathrm{C}$. Illumination was provided by four, three or two $20 \mathrm{~W}$ Daylight fluorescent lamps on each side of the bath, $7.5 \mathrm{~cm}$ from the front edge of the lamp to the centre of test tube, $\left(39^{\circ} \mathrm{C}\right)$ or with two lamps on each side $\left(30^{\circ} \mathrm{C}\right)$. At $39^{\circ} \mathrm{C}$, the same results were obtained irrespective of whether four, three or two lamps were used on each side of the bath. $\mathrm{CO}_{2}$ enriched air $(1 \pm 0 \cdot 1 \%)$ was continuously passed through the test tubes. Growth rates and yields were determined by dry weight measurements: cells were gently filtered on Nucleopore $0.4 \mu \mathrm{m}$ filters, washed carefully with distilled water and dried to constant weight in a vacuum oven at $45^{\circ} \mathrm{C}$ over $\mathrm{P}_{2} \mathrm{O}_{5}$.

Radioactive uptake experiments. Organism $3 \mathrm{NT}$ was grown on limiting nickel $(0.002 \mu \mathrm{M})$ to well beyond nickel deficiency. $3 \mathrm{NT}$ is a filamentous organism, but it breaks up on mild treatment in a hand homogenizer to give reasonably uniform cell suspensions. [2-14 C]Uracil, $\left(2 \mu \mathrm{Ci}\right.$, specific activity $62 \mathrm{mCi} \mathrm{mmol}^{-1}$; Schwarz-Mann, Orangeburg, New Jersey, U.S.A.) was added to $15 \mathrm{ml}$ of homogenized cell suspension containing $0.2 \mathrm{mg}$ dry wt cells $\mathrm{ml}^{-1}$ and the rate of incorporation was observed over a $6 \mathrm{~h}$ period in the light at $39^{\circ} \mathrm{C}$. Uracil has been shown to label RNA and, to some extent, DNA in blue-green algae (Pigott \& Carr, 1971; Glaser et al., 1972). A similar experiment was carried out with [U-14C]leucine (specific activity 330 mCi mmol ${ }^{-1}$; Amersham-Searle, Arlington Heights, Illinois, U.S.A.). The cells were harvested on Gelman $0.45 \mu \mathrm{m}$ filters and rinsed with cold medium ASP-2; the filter was then transferred to a scintillation vial 


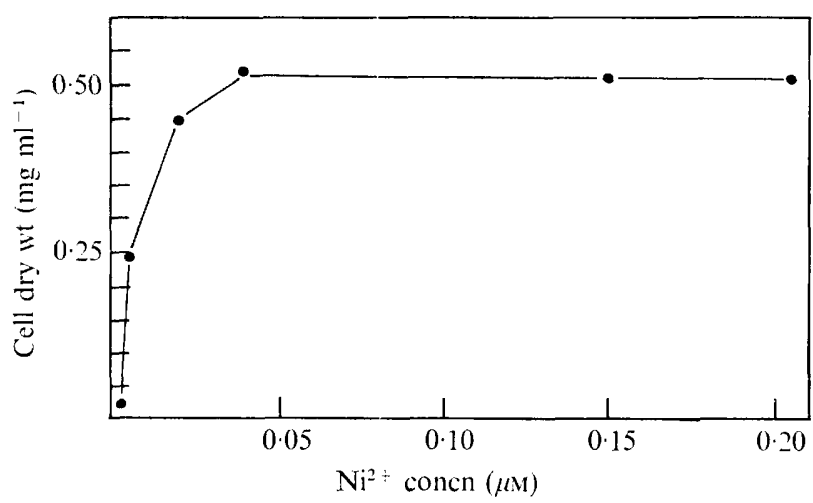

Fig. 1. Yield of Oscillatoria sp. strain 3NT as a function of added nickel. Medium ASP-2 which had not been extracted with 8-hydroxyquinoline was used. The inoculum was grown in the same medium without added nickel (= nickel-deficient cells), and prepared by mild homogenization with glass beads (about $0.18 \mathrm{~mm}$ diam.). Test tubes containing $20 \mathrm{ml}$ medium and about $0.006 \mathrm{mg}$ inoculum were incubated at $39^{\circ} \mathrm{C}$, with three lamps on each side of the bath. Cells were harvested $88 \mathrm{~h}$ after inoculation. There was no inhibition of growth at the highest $\mathrm{Ni}^{2+}$ level tested, i.e. $4 \cdot 2 \mu \mathrm{M}$. Before use, the growth tubes and bubbling tubes were cleaned by soaking in $10 \% \mathrm{HCl}$, rinsing in distilled water, then soaking in $\mathrm{Na}_{4}$ EDTA $\left(50 \mathrm{mg} \mathrm{l}^{-1}\right)$, followed by rinsing in distilled water; other glassware was washed in $\mathrm{HCl}$ and rinsed with distilled water.

containing Soluene 350 (Packard Instrument Co., Downers Grove, Illinois, U.S.A.). After the cells ware digested, Insta-Fluor cocktail (Packard) was added and the samples were counted on a Packard 3255 liquid scintillation spectrometer.

\section{RESULTS AND DISCUSSION}

The generation time of organism $3 \mathrm{NT}$ with a saturating level of nickel at $39^{\circ} \mathrm{C}$, with four, three or two lamps per bank, was rather low - about $15 \mathrm{~h}$. The growth rate was not stimulated by the addition of $\mathrm{NH}_{4} \mathrm{Cl}$ (1 to $2 \mathrm{mM}$ ), suggesting that assimilation of nitrogen was not the cause of the low growth rate. Low levels of nickel saturated the growth of organism 3NT (Fig. 1). The saturating $\mathrm{Ni}^{2+}$ concentration of $0.05 \mu \mathrm{M}$ was somewhat lower than values reported for Alcaligenes strains H1 and H16 (Bartha \& Ordal, 1965; Tabillion \& Kaltwasser, 1977). However, it should be noted that medium ASP-2 contains EDTA $(80 \mu \mathrm{M})$ whereas no EDTA was used in the work with Alcaligenes. We suppose that its presence may facilitate nickel uptake at lower levels by organism 3NT. The P-1 trace metals mix used in medium ASP-2 contained $\mathrm{Co}, \mathrm{Zn}, \mathrm{Mo}, \mathrm{Cu}, \mathrm{Mn}$ and $\mathrm{B}$; and hence the nickel requirement of $3 \mathrm{NT}$ cannot reflect an impurity in the $\mathrm{NiCl}_{2} \cdot 6 \mathrm{H}_{2} \mathrm{O}$ which provided one of these metals. Extraction of medium ASP-2 with 8-hydroxyquinoline caused little change in the results. In medium made with extracted major salts (Gentry \& Sherrington, 1950) without added nickel, growth was not measurable; in unextracted medium, growth was marginal.

Yeast extract or Casamino acids at $50,150,300$ or $1000 \mathrm{mg} \mathrm{l}^{-1}$ did not spare the nickel requirement of organism $3 \mathrm{NT}$. Glucose $(0.011 \mathrm{~m})$ or glycerol $(0.022 \mathrm{M})$ plus Casamino acids $\left(500 \mathrm{mg} \mathrm{1}^{-1}\right)$ also had no sparing effect on the nickel requirement. Casamino acids with or without glucose were previously found to stimulate the growth of some blue-green algae under conditions limiting photoautotrophic growth (Pulich \& Van Baalen, 1974). Their lack of stimulation of $3 \mathrm{NT}$ growth suggests that nickel does not act directly in nitrogen assimilation, or in carbon transformations. A role in electron transport is not excluded by these observations.

The addition of saturating levels of nickel to nickel-deficient cells did not affect the rate of incorporation of $\left[2-{ }^{14} \mathrm{C}\right]$ uracil or $\left[\mathrm{U}-{ }^{14} \mathrm{C}\right]$ leucine over a $6 \mathrm{~h}$ period. Nickel also had no immediate effect on the photosynthetic rate of $3 \mathrm{NT}$ as measured with an oxygen electrode. 
As in the work with the Alcaligenes strains, we were also unable to specify a possible metabolic role for nickel. However, the isolation of strain 3NT does suggest that nickel should be included in any list of required trace metals for blue-green algae.

University of Texas Marine Science Institute Contribution No. 242.

\section{REFERENCES}

Bartha, R. \& ORdal, E. J. (1965). Nickel-dependent chemolithotrophic growth of two Hydrogenomonas strains. Journal of Bacteriology 89, 1015-1019.

Cobet, A. B., Wirsen, C., JR, \& Jones, G. E. (1970). The effect of nickel on a marine bacterium, Arthrobacter marinus sp. nov. Journal of General Microbiology 62, 159-169.

Dixon, N. E., Gazzola, C., Blakeley, R. L. \& ZERNER, B. (1976). Metal ions in enzymes using ammonia or amides. Science 191, 1144-1150.

Fuhrmann, G. \& Rothstein, A. (1968). The mechanism of the partial inhibition of fermentation in yeast by nickel ions. Biochimica et biophysica acta 163, 331-338.

Gentry, C. H. R. \& Sherrington, L. G. (1950). Extraction and photometric estimation of some metals with 8-hydroxyquinoline. Analyst 75, 17-21.

Glaser, V. M., Al-nuri, M. A., Groshev, V. V. \& Shestakov, S.V. (1972). The labelling of nucleic acids by radioactive precursors in the blue-green algae Anacystis nidulans and Synechocystis aquatilis Sanv. Archiv für Mikrobiologie 92, 217-226.

Myers, J. (1950). The culture of algae for physiological research. In The Culturing of Algae, pp. 45-51. Edited by J. Brunel, G. W. Prescott and L. H. Tiffany. Yellow Springs, Ohio, U.S.A.: Charles F. Kettering Foundation.

Pigott, G. H. \& CARR, N. G. (1971). The assimilation of nucleic acid precursors by intact cells and protoplasts of the blue-green alga Anacystis nidulans. Archiv für Mikrobiologie 79, 1-6.

Provasoli, L., Mclaughlin, J. J. A. \& Droop, M. R. (1957). The development of artificial media for marine algae. Archiv für Mikrobiologie 25, 392-428.

Pulich, W. M., JR, \& Van BaAlen, C. (1974), Growth requirements of blue-green algae under blue light conditions. Archives of Microbiology 97, 303-312.

RePaske, R. \& RePaske, A. C. (1976). Quantitative requirements for exponential growth of Alcaligenes eutrophus. Applied and Environmental Microbiology 32, 585-591.

SkaAR, H., Rystad, B. \& Jensen, A. (1974). The uptake of ${ }^{63} \mathrm{Ni}$ by the diatom Phaeodactylum tricornutum. Physiologia plantarum 32, 353-358.

TABILlion, R. \& Kaltwasser, H. (1977). Energieabhängige ${ }^{63} \mathrm{Ni}-A u f n a h m e$ bei Alcaligenes eutrophus Stamm H1 und H16. Archives of Microbiology 113, 145-151.

Van BaAlen, C. (1962). Studies on marine bluegreen algae. Botanica marina 4, 129-139. 